УДК 373.3.016:796.412.2

https://doi.org/10.36906/FKS-2021/59

Красова А.А.

Нижневартовский государственный университет

г. Нижневартовск, Россия

\title{
ОСОБЕННОСТИ СОДЕРЖАНИЯ ВНЕУРОЧНЫХ ЗАНЯТИЙ ПО ХУДОЖЕСТВЕННОЙ ГИМНАСТИКЕ В ШКОЛЕ
}

Аннотация. Здоровье нации - это категория, определяющая социальную стабильность общества. Одним из путей решения этой проблемы может являться внедрение различных направлений художественной гимнастики в систему школьного физкультурного образования. Это будет способствовать обновлению занятий по физической культуре школьников. Основой процесса физического воспитания в школе являются занятия физическими упражнениями эстетической направленности. Они нередко входят в состав мероприятий внеурочной физкультурно-оздоровительной и спортивно-массовой направленности. Особую роль во внеурочной деятельности в школе играют занятия художественной гимнастикой.

Ключевые слова: художественная гимнастика, занятия физической культурой, рабочая программа, гимнастические предметы, упражнения художественной гимнастики.

Krasova A.A.

Nizhnevartovsk State University

Nizhnevartovsk, Russia

\section{SPECIFIC FEATURES OF THE CONTENT OF OUTLOOK RHYTHMIC GYMNASTICS AT SCHOOL}

Annotation. The health of a nation is a category that determines the social stability of a society. One of the ways to solve this problem may be the introduction of various directions of rhythmic gymnastics into the system of school physical education. This will contribute to the renewal of physical education classes for schoolchildren. The basis of the process of physical education at school is physical exercise of aesthetic orientation. They are often included in the activities of extracurricular fitness and sports and mass sports. Rhythmic gymnastics plays a special role in extracurricular activities at school.

Keywords: rhythmic gymnastics, physical education, work program, gymnastic items, rhythmic gymnastics exercises.

Занятия художественной гимнастикой призваны удовлетворить потребность школьниц в физической активности и способствовать их оздоровлению, повышению интереса к ним, приобщению к здоровому образу жизни. Широкая пропаганда художественной гимнастики в средствах массовой информации служит дополнительным и существенным аргументом в пользу выбора школьниками занятий им [6, с. 43].

Художественная гимнастика учит соблюдать правила эстетического поведения, формирует понятия о красоте тела, воспитывает вкус, музыкальность. В процессе занятий формируются жизненно важные двигательные умения и навыки, приобретаются специальные знания, воспитываются моральные и волевые качества [7, с. 87]. 
Систематические занятия художественной гимнастикой способствуют сохранению силы, гибкости, красоты тела, улучшают осанку, походку, позволяют легко переносить нагрузки и производить широкий круг физических действий. Применение разнообразных элементов художественной гимнастики на занятиях во внеурочное время с младшими школьницами позволяют оптимизировать педагогический процесс проведения занятий в системе дополнительного образования младших школьниц [2, с. 386].

Художественная гимнастика открывает огромные возможности для гармоничного физического развития детей и подростков, так как её основа - специально созданные комплексы физических упражнений, а система занятий в целом сочетается с элементами игры, сюжетно-образными упражнениями, танцевальными импровизациями, с использованием предметов (скакалки, обручи, ленты, мячи, булавы). Желание заниматься художественной гимнастикой стало актуальным направлением среди девочек младших классов.

Отличительной особенностью федерального государственного образовательного стандарта является его деятельностный характер, ставящий главной целью развитие личности учащегося [3, с. 35,4 , с. 33].

Активная двигательная деятельность ведет к росту культуры наших взглядов на здоровье, к изменению режима труда, отдыха, питания, требованиям к личной гигиене, закаливанию. Она может перестроить многое в характере и привычках, заставив отказаться в дальнейшем от наиболее вредных из них.

Именно в младшем школьном возрасте родители и учителя физической культуры должны сформировать оптимальную двигательную активность, потребность у ребёнка в движениях, мышечной деятельности, и тогда, становясь взрослее, обучающийся будет больше двигаться ввиду сложившейся привычки [1, с. 5].

Уроки физической культуры в школах не полностью восполняют дефицит двигательной активности. Поэтому, в начальной школе назревает необходимость введения занятий технико-эстетическими видами спорта во внеурочную деятельность, которая будет направлена на укрепление здоровья детей. Однако, изученная литература свидетельствует о том, что до сих пор недостаточно полно разработаны методики и технологии проведения занятий художественной гимнастикой в процессе внеурочной деятельности.

Таким образом, имеет место противоречие между необходимостью введения художественной гимнастики во внеурочное время и недостаточной разработанностью методик и технологий проведения занятий такого типа и вида. В связи с этим актуальным является исследование особенностей физкультурно-оздоровительной и внеурочной работы по художественной гимнастике со школьниками младших классов. Цель исследования: модернизация рабочей программы по художественной гимнастике для проведения внеурочных занятий в школе. Объект исследования: учебно-воспитательный процесс проведения внеурочных занятий по художественной гимнастике в школе. Предмет исследования: особенности применения разнообразных средств художественной гимнастики на внеурочных занятиях в младших классах.

Практическая значимость заключается в том, что результаты исследования могут быть использованы учителями физической культуры на внеурочных занятиях по художественной гимнастике в общеобразовательных школах. Исследования проводили на базе СОШ № 6 г. Радужный. В нем приняли участие 20 школьниц, обучающихся в младших классах.

В разработанной программе выделены следующие разделы: «Знания о физической культуре», «Способы физкультурной деятельности» и «Физическое совершенствование». В тематическом планировании отражены темы основных разделов программы и характеристики видов деятельности учащихся. Эти характеристики ориентируют учителя физической 
культуры на результаты педагогического процесса, которые должны быть получены в конце освоения содержания учебного материала. Для более качественного освоения содержания программы рекомендуется занятия художественной гимнастикой подразделять на три типа: с образовательно-познавательной, образовательно-предметной и образовательнотренировочной направленностью [5, с. 48].

Особое внимание необходимо уделять развитию гибкости, упражнениям на координацию, общей физической подготовке, а также предметной подготовке (прыжкам на скакалке, развивающим играм с мячом, упражнениям на ловкость и координацию с обручем). Цель модернизированной программы: создать условия для формирования здоровой и гармонично развитой личности обучающихся в младших классах.

В программе выделены следующие задачи: укрепление здоровья, формирование правильную и коррекция правильной осанки, развитие основных видов движений, характерных для художественной гимнастики, а также двигательных качеств, освоение подготовительных иподводящих упражнений, основных элементов художественной гимнастики, применение элементарных движений классического и народного танца, игр и импровизацию под музыку. Через занятия художественной гимнастикой во внеурочное время идет формирование устойчивого интереса к здоровому образу и стилю жизни, обеспечивается эмоциональная комфортность в коллективе, повышается интерес к систематическим занятиям, дисциплинированность и старательность.

Представленная программа разработана на основе дидактических принципов обучения: сознательности, активности, наглядности, доступности и систематичности. К числу наиболее достигаемых в программе целей запланировано:

- организация полноценного досуга, наполняя его активно-деятельным, эмоционально и психологически комфортным содержанием;

- выявление и развитие личностных качества ребёнка, его одарённость через обучение художественной гимнастике;

- помощь в организации ребёнку здорового образа и стиля жизни;

- привитие аккуратности, культуры поведения, умения ценить эстетику и красоту;

- приобщение к культурным ценностям нашей страны.

Планируются проведение занятий художественной гимнастикой в игровой форме, в основе которой лежит партнерская позиция взрослого, личностно-ориентированное отношение к ребенку и непринужденная форма организации физкультурно-оздоровительной деятельности. Игровые приемы будут обеспечивать динамичность процесса обучения, максимально удовлетворять потребности ребенка в двигательной активности. Музыкальное сопровождение подвижных игр поднимет настроение, побудит детей к самовыражению творчества в движениях и повышении их самооценки. Использование здоровьесберегающих технологий благоприятно будут воздействовать на психофизическое здоровье ребенка. Применение разнообразных элементов художественной гимнастики на занятиях во внеурочное время с младшими школьницами позволяют оптимизировать педагогический процесс проведения занятий в системе дополнительного образования младших школьниц.

\section{Литература}

1. Андреева Н.О. Процесс обучения элементам художественной гимнастики (технике бросков и ловли мяча) на уроках физической культуры в средней школе как один из средств развития ловкости и гибкости у младших школьников // Педагогика, психология и медикобиологические проблемы физического воспитания и спорта, 2011. № 4. С. 3-6 . 
2. Архипова Ю.А., Онучин Л.А., Артемьева Ж.С. Художественная гимнастика физкультурно-спортивной направленности в системе дополнительного школьного образования // Актуальные проблемы внедрения комплекса ГТО и развития массового спорта: Материалы Всероссийской научно-практической конференции. Белгород, 2016. С. 385-389.

3. Байер В.В., Муллагильдина А.Я. Составления тренировочных комбинаций на различные виды координационных способностей на этапе предварительной базовой подготовки в художественной гимнастике (на примере упражнений с булавами) // Физическое воспитание студентов творческих специальностей, 2004. № 2. С. 31-36.

4. Поздеева Е.А., Пшеничникова Г.Н., Коричко Ю.В. Модельные характеристики содержания соревновательных упражнений квалифицированных гимнастов в спортивной аэробике // Теория и практика физической культуры. 2018. № 10. С. 33-35.

5. Пшеничникова Г.Н., Власова О.П., Коричко Ю.В. Обоснование рассредоточенного применения упражнений на гибкость в художественной гимнастике на этапе начальной подготовки // Физическая культура: воспитание, образование, тренировка. 2010. № 5. С. 42-49.

6. Пшеничникова Г.Н., Коричко Ю.В., Печеневская Н.Г. Эволюция содержания ритмопластических движений в процессе становления художественной гимнастики // Физическая культура: воспитание, образование, тренировка. 2016. № 5. С. 41-44.

7. Чепурина О.В., Закорко И.П., Журавель А.В. и др. Использование средств и методов художественной гимнастики на уроках «основы здоровья и физической культуры» в младших классах средней школы // Физическое воспитание студентов творческих специальностей. 2002. № 4. С. 86-97. 